\title{
Enzyme-immunoassay for determination of progesterone in milk from cows
}

\author{
K. I. Arnstadt and W. F. Cleere* \\ Institut für Physiologie, Südd. Versuchs- und Forschungsanstalt für Milchwirtschaft der \\ Technischen Universität München, D-8050 Freising-Weihenstephan, West Germany
}

\begin{abstract}
Summary. An enzyme-immunoassay using horseradish peroxidase as label is described. The assay has a sensitivity of $0.1-20$ pmol, i.e. $0.03-0.63 \mathrm{ng}$ and intraand inter-assay coefficients of variation of $<10 \%$ when used for the determination of progesterone in samples of milk from cows. Comparison with a radio-immunoassay based on tritiated tracer showed excellent correlation $(r=0.98)$ for milk samples from cows during the oestrous cycle and early pregnancy.
\end{abstract}

\section{Introduction}

The concentration of progesterone in milk reflects that in plasma (serum) samples (McCracken, 1964), and the determination of progesterone in milk samples can give valuable information about the physiological status of the cow (Laing \& Heap, 1971; Heap, Gwyn, Laing \& Walters, 1973; Hoffmann \& Hamburger, 1973). The most popular assay for this purpose has been radioimmunoassay (RIA) using tritiated progesterone as label (Heap et al., 1973; Hoffmann \& Hamburger, 1973; Heap, Holdsworth, Gadsby, Laing \& Walters, 1976), but an alternative RIA using progesterone labelled with ${ }^{125} \mathrm{I}$ has been proposed (Allen, Redshaw \& Holdsworth, 1980; Stupnicki \& Kula, 1981). While both of these methods can give accurate and reliable results they suffer from the problems associated with the use of radioisotopes, e.g. short shelf life of label $\left({ }^{125} \mathrm{I}\right)$, cost of scintillators and radioactive waste disposal $\left({ }^{3} \mathrm{H},{ }^{14} \mathrm{C}\right)$, and restriction to institutes which have permission and facilities to handle radioisotopes (Ekins, 1977; Schuurs \& van Weemen, 1977). Such problems have prompted the search for alternative labels for use in immunoassays. Proposed alternatives include: enzymes, erythrocytes, bacteriophages, fluorescent groups, and stable free radicals. Of these labels, enzymes have received by far the greatest attention because enzyme markers offer the best possibility of achieving assays with sensitivity, reproducibility and practicability similar to those of radioimmunoassays (for review see Wisdom, 1976; Schuurs \& van Weemen, 1977; Voller, Bartlett \& Bidwell, 1978). Enzymeimmunoassays (EIA) for proteins and bacterial antigens have been readily developed but those for steroid hormones posed greater difficulties and only recently has some improvement in this area been achieved (for review see $\mathrm{Pal}, 1978$ ). These developments, together with the advantages to be gained from the use of a non-radioisotopic label, prompted us to investigate the application of an enzyme-immunoassay modified from that of Joyce, Read \& Fahmy (1977) to the determination of progesterone in milk.

Brief reports of these results have been published (Arnstadt \& Cleere, 1980, 1981).

* Present address: Biochemistry Department, University College Galway, Galway, Ireland. 


\section{Materials and Methods}

Reagents. Horseradish peroxidase (EC 1.11.1.7) with an R.Z. of approximately 3.0, progesterone, $11 \alpha$-hydroxyprogesterone, 11-ketoprogesterone, $20 \alpha$-dihydroprogesterone, $20 \beta$ dihydroprogesterone, oestradiol-17 $\beta$, and cholesterol were purchased from Sigma, München, West Germany; $11 \alpha$-hydroxyprogesterone-11-hemisuccinate, 17 $\alpha$-hydroxyprogesterone, $5 \beta$ pregnane-3,20-dione, deoxycorticosterone, corticosterone and cortisol from Steraloids, Wilton, New Hampshire, U.S.A.; bovine serum albumin from Behringwerke AG, Marburg, West Germany; cyanogen bromide and isobutylchloroformate from Fluka, Buchs, Switzerland; and sodium chloride from Roth, Karlsruhe, West Germany. All other reagents were of high purity and were purchased from Merck, Darmstadt, West Germany. Organic solvents were distilled before use.

Buffers. Buffer A contained 0.01 M-sodium phosphate, $0.15 \mathrm{M}$-sodium chloride and $0 \cdot 1 \%$ bovine serum albumin at $\mathrm{pH} 7.4$. Buffer $\mathrm{B}$ consisted of $0.2 \mathrm{M}$-sodium phosphate, $\mathrm{pH} 6.0$. The buffer-substrate solution for peroxidase determination contained $6.0 \mathrm{~mm}$-hydrogen peroxide and $3.7 \mathrm{mM}-o$-phenylenediamine in Buffer B. It was stored not longer than 1 day in the dark at $4^{\circ} \mathrm{C}$.

Conjugates. The test reagents, progesterone-horseradish peroxidase and the solid-phase antibody for this EIA, obtainable now from Biolab, München, West Germany, were prepared by the following procedures: Horseradish peroxidase was coupled to the $11 \alpha$-hydroxy-hemisuccinate of progesterone by the mixed anhydride method of Erlanger, Borek, Beiser \& Liebermann (1957) as modified by Joyce et al. (1977). Separation of the conjugate from any remaining low molecular weight material was achieved by chromatography on Sephadex G 25 . The charge number of the conjugate (progesterone/enzyme ratio) approached the theoretical ideal value of 1.0 as estimated by RIA. The conjugate was highly stable and freeze-dried preparations showed no loss of enzymic or immunological activity after almost 1 year at $4^{\circ} \mathrm{C}$. Working solutions $(0.01 \mathrm{mg} / \mathrm{ml})$ can be kept refrigerated for at least 1 month.

Antiserum against an $11 \alpha$-hydroxyprogesterone-bovine serum albumin conjugate was raised in rabbits (Hoffmann, Kyrein \& Ender, 1973) and used for both enzyme-immunoassay and radio-immunoassay. For the enzyme-immunoassay, the solid-phase antiserum was coupled to microcrystalline cellulose by a cyanogen bromide method (Axén, Porath \& Ernback, 1967).

Milk samples. Samples were taken daily from whole bulk milk (evening milking) from 3 cows (local Brown Swiss breed) during the oestrous cycle, and from one of these cows for an additional period after insemination. Milk was stored at $-18^{\circ} \mathrm{C}$ until required for preparation of fat. Fat, which contains most of the progesterone present in milk (Hoffmann \& Hamburger, 1973; Heap, Linzell \& Laing, 1974; Heap, Henville \& Linzell, 1975; Hoffmann, Hamburger \& Hollwich, 1977), was prepared according to the method of Claus \& Rattenberger (1979). Aliquots $(5 \mu \mathrm{l})$ were dispensed into petroleum ether and progesterone was extracted into a methanol-water phase which was dried in a vacuum oven at $40^{\circ} \mathrm{C}$ (Hoffmann et al., 1977).

Progesterone standards. Progesterone was stored in ethanol at $4^{\circ} \mathrm{C}$ at a concentration of $1.0 \mathrm{~mm}$. When required dilutions were prepared in ethanol. Tubes containing standards were dried under nitrogen or in a vacuum oven at $40^{\circ} \mathrm{C}$.

\section{Enzyme-immunoassay procedure}

The enzyme-labelled progesterone ( $50 \mathrm{fmol})$ and an appropriate dilution of cellulose-bound antiserum in a final volume of $0.5 \mathrm{ml}$ PBS/BSA were added to the tubes (tests and standards). The tube contents were mixed and incubated at $37^{\circ} \mathrm{C}$ for a total of 30 min, including a second mixing after $15 \mathrm{~min}$. The tubes were then incubated in an icebath for $1 \mathrm{~h}$ or longer. If necessary this incubation can take place overnight.

Separation of free from bound label was achieved by centrifugation. After incubation, a 
solution $(0.2 \mathrm{ml})$ of microcrystalline cellulose $(50 \mathrm{mg} / 30 \mathrm{ml}$ Buffer $\mathrm{A})$ was then added to each tube, followed by $4.0 \mathrm{ml}$ Buffer B. After mixing and centrifuging $\left(2000 \mathrm{~g}\right.$ for $15 \mathrm{~min}$ at $\left.4^{\circ} \mathrm{C}\right)$ the supernatant was decanted and the washing step repeated. The bound label was measured by determining the peroxidase activity of the cellulose pellets. To each pellet was added $2.0 \mathrm{ml}$ buffer-substrate solution. Following mixing and incubation in the dark at room temperature for 20-60 min the reaction was stopped by the addition of $0.4 \mathrm{ml} 10 \mathrm{~N}-\mathrm{H}_{2} \mathrm{SO}_{4}$. The sample was centrifuged ( $2000 \mathrm{~g}$ for $15 \mathrm{~min}$ ) and the change in absorbance of the supernatant at $492 \mathrm{~nm}$ was measured. Under the assay conditions used, this value is directly proportional to the peroxidase content, and hence to the content of bound label.

\section{Radio-immunoassay}

The radio-immunoassay was that of Hoffmann et al. $(1973,1977)$ which uses tritiated progesterone as label and a dextran-coated charcoal separation step.

\section{Results}

Text-figure 1 shows a typical standard curve for progesterone determination by enzymeimmunoassay. The range covered is appropriate to the present application. For comparison a standard curve for the radio-immunoassay used routinely in this laboratory is also included.

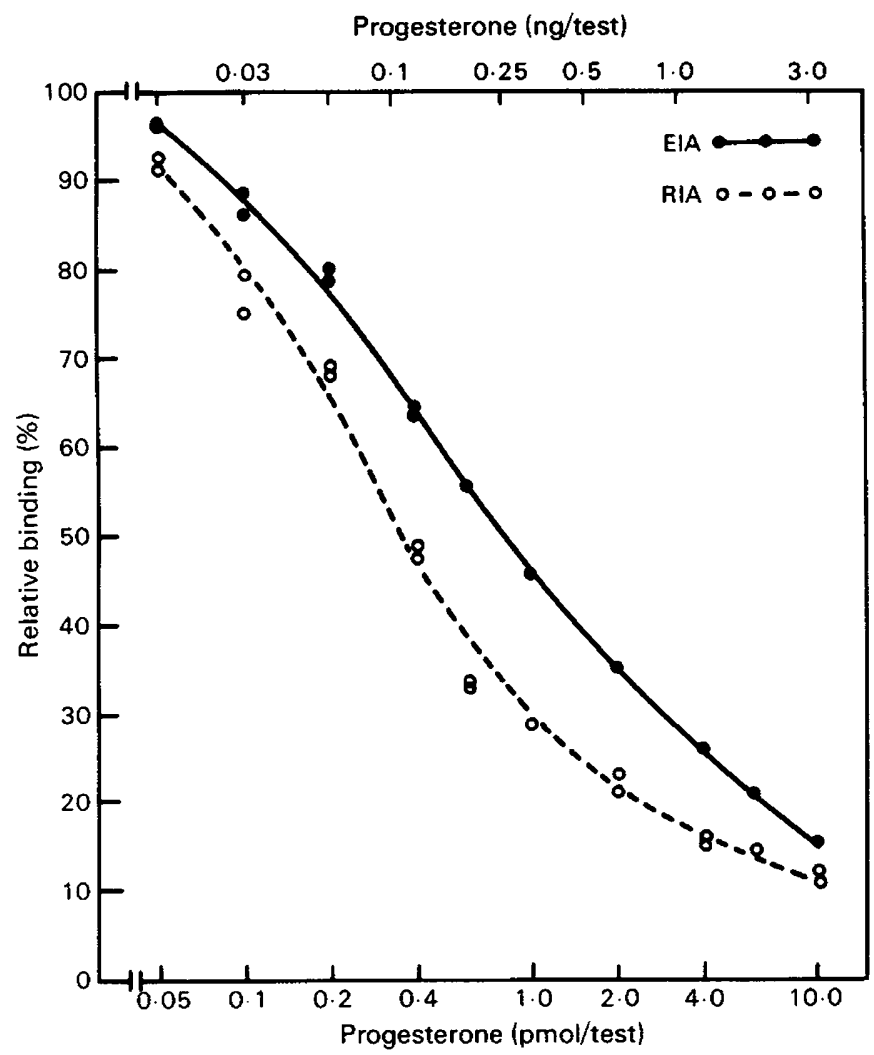

Text-fig. 1. Standard curves for progesterone determination by enzyme-immunoassay and radio-immunoassay. 


\section{Validation of the assay}

Specificity. Table 1 shows the cross-reactions of some steroids in the two assays. The enzyme-immunoassay is at least as specific as the radio-immunoassay using the same original antiserum against $11 \alpha$-hydroxyprogesterone.

Table 1. Cross-reactions* of various steroids in the enzyme-immunoassay and radio-immunoassay

\begin{tabular}{lcc}
\hline & \multicolumn{2}{c}{ \% Cross-reaction } \\
\cline { 2 - 3 } \multicolumn{1}{c}{ Steroid } & Enzyme-immunoassay & Radio-immunoassay \\
\hline Progesterone & 100 & 100 \\
11a-Hydroxyprogesterone & 18.5 & 73.6 \\
11-Ketoprogesterone & 8.0 & 78.0 \\
17a-Hydroxyprogesterone & 0.57 & 3.3 \\
20a-Dihydroprogesterone & 0.4 & 17.8 \\
20ß-Dihydroprogesterone & 1.26 & 0.26 \\
$5 \beta$-Pregnane-3,20-dione & 28.0 & 28.9 \\
Deoxycorticosterone & 5.8 & 4.8 \\
Corticosterone & 2.2 & 2.6 \\
Cortisol & $<0.73$ & $<0.07$ \\
Oestradiol-17 $\beta$ & $<0.73$ & $<0.07$ \\
Cholesterol & $<0.0005$ & $<0.0005$ \\
\hline
\end{tabular}

Defined as (pmol progesterone displacing 50\% of label/pmol steroid displacing 50\% of label) $\times 100$.

Recovery and dilution experiments. Table 2 shows that the recovery of different amounts of progesterone added to the milk fat of oestrous cows is satisfactory. Determinations of the progesterone concentrations in different volumes by enzyme-immunoassay $(1,2,3,4$ and $5 \mu \mathrm{l})$ of milk fat gave constant values $(1 \cdot 16,1 \cdot 18,1 \cdot 13,1 \cdot 10$ and $1 \cdot 14 \mathrm{pmol} / \mu \mathrm{l})$, respectively.

Table 2. Recovery of progesterone from the fat in milk from oestrous cows

\begin{tabular}{ccc}
\hline $\begin{array}{c}\text { Progesterone added } \\
\text { (pmol) }\end{array}$ & $\begin{array}{c}\text { Progesterone } \\
\text { recovered } \\
\text { (pmol) }\end{array}$ & $\begin{array}{c}\text { \% Recovery of progesterone } \\
\text { after correction for } \\
\text { blank }\end{array}$ \\
\hline 0 & $0.108^{*}$ & - \\
0.3 & 0.396 & 96.0 \\
0.6 & 0.64 & 88.6 \\
1.0 & 1.05 & 94.2 \\
2.0 & 2.20 & 104.6 \\
\hline
\end{tabular}

* Endogenous progesterone content of $5 \mu \mathrm{l}$ fat in milk from oestrous cows.

Precision. The intra- and inter-assay coefficients of variation are within acceptable limits, 4.8 to $7.7 \%(n=30)$ and 7.4 to $9.2 \%(n=44)$.

Comparison with radio-immunoassay results. Milk samples were collected and prepared as described above. Progesterone was determined by enzyme-immunoassay and by radioimmunoassay (Text-fig. 2). Correlation between the values obtained by the two methods is good $(r=0.98, n=25)$.

Physiological results. The enzyme-immunoassay has been applied to obtain progesterone profiles from 1 cow during a normal oestrous cycle with subsequent period of early pregnancy after insemination and from 2 cows with post-partum cycles (Text-fig. 3). The latter seemed to 


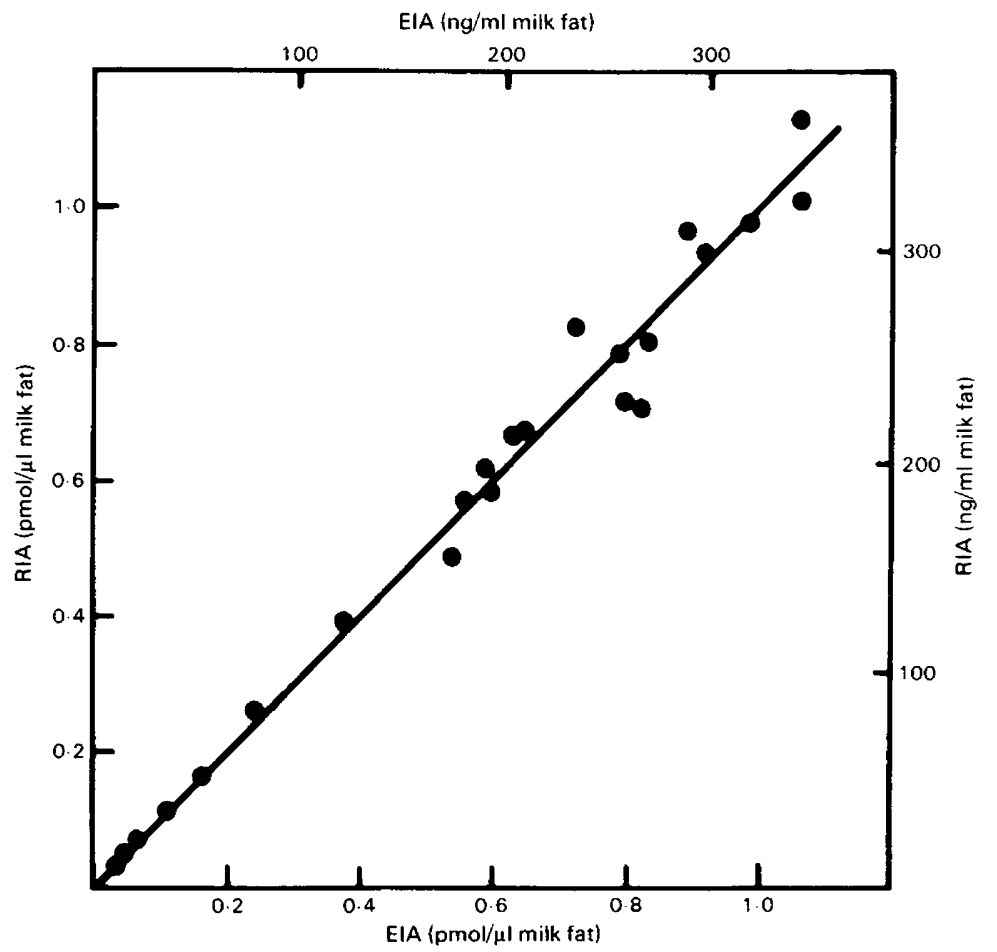

Text-fig. 2. Correlation between milk-fat progesterone values determined by enzyme-immunoassay and radio-immunoassay.

be prolonged but were almost within the ranges which occur in a certain percentage of cows that are physiologically normal and without any apparent clinical abnormalities (Bulman \& Lamming, 1977). An abnormal LH pattern causing a 30-day cycle has been put forward to explain this phenomenon (Karg, Hoffmann \& Schams, 1970). The profiles obtained by the enzyme-immunoassay showed the typical pattern and were further validated by parallel determination of the progesterone content of the milk samples by radio-immunoassay. The curves obtained by both methods show close agreement.

\section{Discussion}

Analysis of progesterone in milk plays an important role in the herd management and veterinary control of cows. In particular, progesterone determination is applicable to evaluation of the appropriate timing of (artificial) insemination during assumed oestrus; confirmation of return or of non-return of oestrus; monitoring of cyclicity during the post-partum period; monitoring veterinary therapautic measures; and monitoring during special programmes such as those with embryo transfer experiments (Karg, Claus, Hoffmann, Schallenberger \& Schams, 1976; Günzler et al., 1979; Karg et al., 1980).

Although RIA procedures for progesterone determination have been successfully used in several countries (see British Veterinary Journal, Vol. 132, 1976), there is still a need for a more readily available assay having the same reliability as RIA. We feel that the EIA reported here fulfils this demand. 


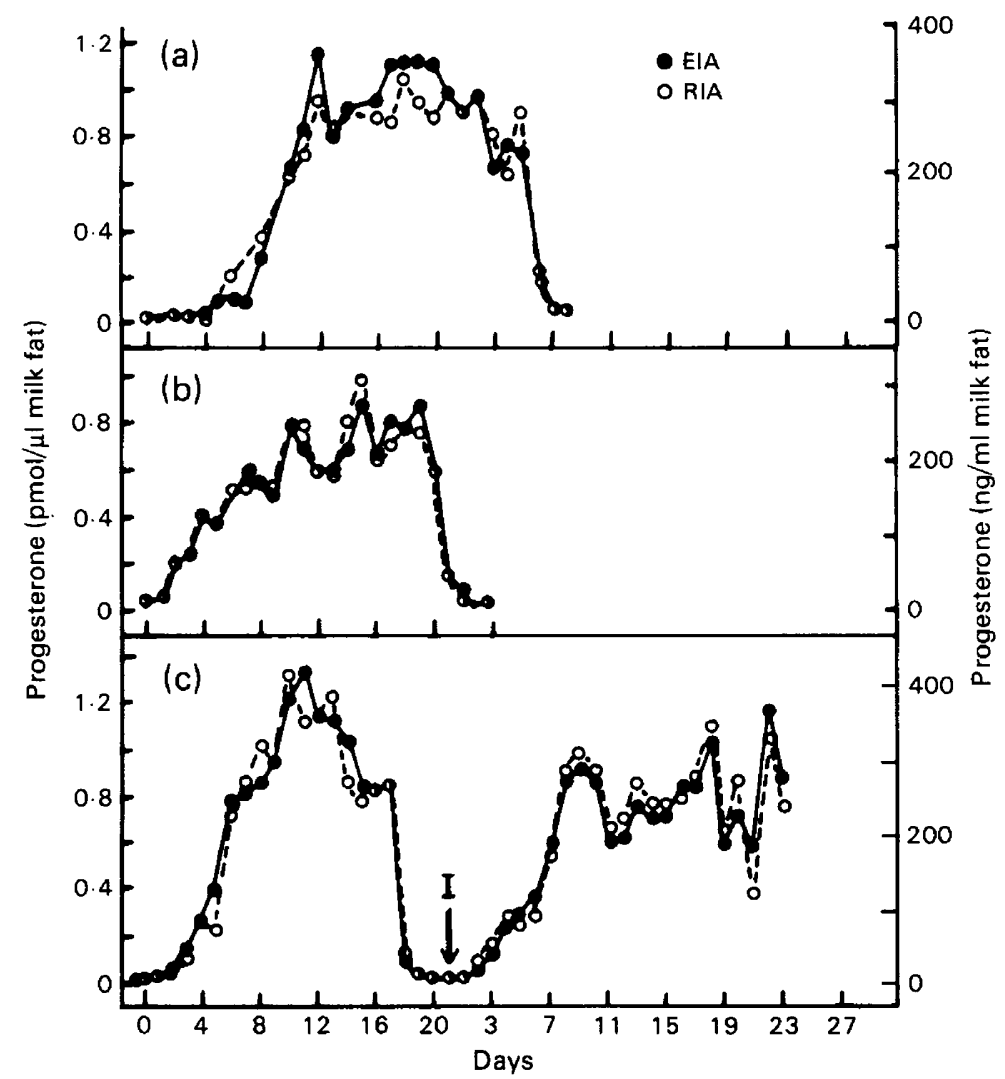

Text-fig. 3. Concentrations of progesterone, measured by enzyme-immunoassay ( $)$ and radio-immunoassay (O), in milk from ( $a, b) 2$ cows during the oestrous cycle and (c) 1 cow during an oestrous cycle and in early pregnancy after insemination (I) as indicated. Oestrus occurred at Day 0.

An EIA for progesterone determination in blood plasma has been applied by Kamonpatana et al. (1979) to swamp buffalo for early diagnosis of pregnancy, but the EIA values differed considerably from the RIA results (30-153\% of the RIA value) so their method seemed to be rather unreliable and clearly needed to be improved. The cross-reactions in our EIA are lower than those for the RIA for some compounds (Table 1). Specificities of the EIA as good or better than those of the RIA have been reported for steroids (Joyce et al., 1977; Abuknesha \& Exley, 1978; Rajkowski, Cittanova, Desfosses, Urios \& Jayle, 1978), and we are now investigating whether this is a general characteristic of this type of EIA.

The reliability of our EIA is shown by the control data and by the physiological results. In addition, the assay has been running without technical difficulties in our institute for 1 year. The EIA can be readily performed in any laboratory which has the basic equipment of a centrifuge and colorimeter. The only apparent disadvantage of the enzyme-immunoassay described here is a requirement for additional washing of the cellulose pellets and in part by the enzyme measurement itself. This factor could, in certain circumstances, offset any cost savings made by working with a non-radioisotopic label. However for large scale applications, for which automation is economically justified, the greater amount of work is not a big disadvantage.

We conclude that (1) this enzyme-immunoassay is a suitable alternative to radio- 
immunoassay for milk progesterone determination; (2) enzyme-immunoassay should prove attractive to those wishing to perform such determinations but who lack radio-immunoassay facilities; and (3) enzyme-immunoassay should also present an attractive alternative for laboratories having to expand or overhaul their existing radio-immunoassay facilities.

This work was supported by the Bundesministerium für Forschung und Technologie, Bonn. The expert technical assistance of Mrs Margot Gellermann is gratefully acknowledged.

\section{References}

Abuknesha, R. \& Exley, D. (1978) Design and development of oestradiol-17 $\beta$ enzyme-immunoassay. In Enzyme Labelled Immunoassay of Hormones and Drugs, pp. 139-152. Ed. S. B. Pal. Walter de Gruyter, Berlin.

Allen, R.M., Redshaw, M.R. \& Holdsworth, R. (1980) A comparison of tritiated and iodinated tracers in the radioimmunoassay of progesterone in cow milk. $J$. Reprod. Fert. 58, 89-93.

Arnstadt, K.I. \& Cleere, W.F. (1980) Anwendung eines Enzymimmunoassays (EIA) zur Progesteronbestimmung in der Milch. Zuchthygiene 15, 74, Abstr.

Arnstadt, K.I. \& Cleere W.F. (1981) Enzyme-immunoassay for progesterone applied to milk samples. In Applications of Radioimmunoassay and Related Methods in Animal Science, Warsaw, Ed. R. Stupnicki. (in press).

Axén, R., Porath, J. \& Ernback, S. (1967) Chemical coupling of peptides and proteins to polysaccharides by means of cyanogen halides. Nature, Lond. 214, 1302-1304.

British Veterinary Journal (1976) Special issue: Progesterone in milk and pregnancy diagnosis. Vol. 132, 443-550.

Bulman, D.C. \& Lamming, G.E. (1977) Cases of prolonged luteal activity in the non-pregnant dairy cow. Vet. Rec. 100, 550-552.

Claus, R. \& Rattenberger, E. (1979) Improved method for progesterone determination in milk fat. Br.vet. J. $135,448-453$.

Ekins, R.P. (1977) The future development of immunoassay. In Radioimmunoassay and Related Procedures in Medicine, Vol. I, pp. 241-275. Int. Atomic Energy Agency, Vienna.

Erlanger, B., Borek, F., Beiser, S.M. \& Liebermann, S. (1957) Steroid-Protein Conjugates. I. Preparation and characterization of conjugates of bovine serum albumin with testosterone and with cortisone. J. biol. Chem. 228, 713-727.

Günzler, O., Rattenberger, E., Görlach, A., Hahn, R., Hocke, P., Claus, R. \& Karg, H. (1979) Milk progesterone determination as applied to the confirmation of oestrus, the detection of cycling and as an aid to veterinarian and biotechnical measures in cows. Br. vet. J. 135, 541-549.

Heap, R.B., Gwyn, M., Laing, J.A. \& Walters, D.E. (1973) Pregnancy diagnosis in cows; changes in milk progesterone concentration during the oestrous cycle and pregnancy measured by a rapid radioimmunoassay. J.agric. Sci., Camb. 81, 151-157.

Heap, R.B., Linzell, J.L. \& Laing, J.A. (1974) Pregnancy diagnosis in cows: use of progestagen concentration in milk. Vet. Rec. 94, 160.
Heap, R.B., Henville, A. \& Linzell, J.L. (1975) Metabolic clearance rate, production rate, and mammary uptake and metabolism of progesterone in cows. $J$. Endocr. 66, 239-247.

Heap, R.B., Holdsworth, R.J., Gadsby, J.E., Laing, J.A. \& Walters, D.E. (1976) Pregnancy diagnosis in the cow from milk progesterone concentration. Br.vet.J. $132,445-464$.

Hoffmann, B. \& Hamburger, R. (1973) Progesteron in der Milch: Radioimmunologische Bestimmung, Beziehungen zur Gelbkörperfunktion und Milchfettkonzentration. Zuchthygiene 8, 154-162.

Hoffmann, B., Kyrein, H.J. \& Ender, M.L. (1973) An efficient procedure for the determination of progesterone by radioimmunoassay applied to bovine peripheral plasma. Hormone Res. 4, 302-310.

Hoffmann, B., Hamburger, R. \& Hollwich, W. (1977) Bestimmung von Progesteron direkt in Milchfett als verbessertes Verfahren zur Fertilitätskontrolle bei der Kuh. Zuchthygiene 12, 1-7.

Joyce, B.G., Read, G.F. \& Fahmy, D.R. (1977) A specific enzyme-immunoassay for progesterone in plasma. Steroids 29, 761-770.

Kamonpatana, M., van de Wiel, D.F.M., Koops, W., Leenanuruksa, D., Ngramsuriyaroj, C. \& Usanakornhue, S. (1979) Oestrus control and early pregnancy diagnosis in the swamp buffalo: comparison of enzyme-immunoassay and radio-immunoassay for plasma progesterone. Theriogenology 11, 399-409.

Karg, H., Hoffmann, B. \& Schams, D. (1970) Luteinizing hormone, prolactin and progesterone relationship in vivo (data from the cow). Excerpta Medica, Int. Congr. Series No. 219, pp. 691-698.

Karg, H., Claus, R., Hofimann, B., Schallenberger, E. \& Schams, D. (1976) Present status and future possibilities of radioimmunoassay in animal production. In Nuclear Techniques in Animal Production and Health, pp. 487-511. Int. Atomic Energy Agency, Vienna.

Karg, H., Claus, R., Günzler, O., Rattenberger, E., Hahn, R. \& Hocke, P. (1980) Milk progesterone assay for assessing cyclicity and ovarian dysfunction in cattle. Proc. 9th Int. Cong. Anim. Reprod. \& A.I., Madrid, Vol. II, pp. 119-124.

Laing, J.A. \& Heap, R.B. (1971) The concentration of progesterone in the milk of cows during the reproductive cycle. Br. vet.J. 127, XIX.

McCracken, J.A. (1964) Distribution of progesterone in body fluids and tissues of the dairy cow. Ph.D. thesis, University of Glasgow.

Pal, S.B. (Ed.) (1978) Enzyme Labelled Immunoassay of Hormones and Drugs. Walter de Gruyter, Berlin. 
Rajkowski, U.M., Cittanova, N., Desfosses, B., Urios, P. \& Jayle, M.F. (1978) An enzyme-labelled immunoassay of testosterone. In Enzyme Labelled Immunoassay of Hormones and Drugs, pp. 311-326. Ed. S. B. Pal. Walter de Gruyter, Berlin.

Schuurs, A.H.W.M. \& van Weemen, B. (1977) Enzyme immunoassay. Clin. Chim. Acta 81, 1-40.

Stupnicki, R. \& Kula, E. (1981) Direct radioimmunoassay of progesterone in milk and plasma by using a
${ }^{125}$ I-labelled derivative. In Applications of Radioimmunoassay and Related Methods in Animal Science, Warsaw, Ed. R. Stupnicki. (in press).

Voller, A., Bartlett, A. \& Bidwell, D.E. (1978) Enzyme immunoassay with special reference to ELISA techniques. J. clin. Path. 31, 507-520.

Wisdom, G.B. (1976) Enzyme-immunoassay. Clin. chem. 22, 1243-1255.

Received 7 August 1980 